\section{PŘEKLAD 11. REVIZE MEZINÁRODNÍ KLASIFIKACE NEMOC}

\section{Kateřina Hanušová, Šárka Daňková, Dana Krejčová, Miroslav Zvolský}

\section{Anotace}

Mezinárodní klasifikace nemocí (MKN) je publikace Světové zdravotnické organizace (WHO), která kodifikuje systém klasifikace onemocnění, poruch, zdravotních problémů a dalších stavů, situací či okolností souvisejících se zdravím. Po rozsáhlém přepracování stávající (10. verze) klasifikace vyústila 11. revize MKN (MKN-11) v přeformulovanou strukturu a rozšířený detailnější obsah, který zahrnuje více než 120 tisíc klinických termínů.

Ústav zdravotnických informací a statistiky České republiky (ÚZIS ČR) v rámci projektu Národního centra pro medicínské nomenklatury a klasifikace (NCMNK) zahajuje $v$ letošním roce překlad MKN-11 do českého jazyka ve spolupráci s WHO. Překladem je míněno vyhledání odpovídajících odborných termínů ekvivalentních k anglickému mezinárodnímu originálnímu vydání a zároveň rešerše dalších českých termínů se stejným či podobným významem a jejich zařazení $v$ rámci struktury MKN11. Tento překlad zároveň koordinujeme $s$ dalšími středoevropskými zeměmi včetně sdílení zkušeností a kapacit. Překlad bude vytvářen $v$ součinnosti $s$ klinickými experty nominovanými Českou lékařskou společností Jana Evangelisty Purkyně a bude připomínkován dalšími institucemi, např. Ministerstvem zdravotnictví a Českým statistickým úřadem.

Výsledek překladu bude zveřejněn v elektronických nástrojích (webový portál, rozhraní webových služeb/API) vytvářených WHO. Na vlastní překlad bude navazovat testování správnosti a kompletnosti přeložené verze. Překlad MKN-11 by měl být dokončen v roce 2022.

\section{Klíčová slova}

Mezinárodní klasifikace nemocí, medicínská terminologie, MKN-11, $M K N-10$, preklad, implementace

\section{1 Úvod}

V České republice je od roku 1994 aktuálně platná 10. revize klasifikace MKN-10. Její příprava probíhala ve spolupráci s řadou odborníků, včetně zástupců českých odborných společností. Přesto překlad, príprava a implementace MKN-10 nebyla zdaleka ideálně připravena a realizována i vzhledem k rozsahu a významu použití MKN-10, který v průběhu let narůstal. S některými nedostatky zavedení a používání se v kódování zdravotní péče a sběru dat potýkáme dodnes.

MKN-10 se v ČR využívá v rámci četných evidencí a statistik, jako např. kódování příčin smrti na Listu o prohlídce zemřelého, vykazování poskytnuté zdravotní péče, vedení zdravotnické dokumentace, vykazování pracovní neschopnosti a $v$ dalších zdravotnických systémech, má tedy široké uplatnění. V současné době aktuální verze klasifikace nevyhovuje řadě požadavků jejího odborného využití. V zájmu zvýšení kvality stávajících informačních systémů a sběrů dat ve zdravotnictví a v zájmu zachování dostupnosti mezinárodních srovnání je žádoucí v budoucnu přejít na 11. revizi MKN.

Na rozdíl od předchozích revizí, které byly vytvářeny jako informační produkt v knižní podobě, MKN-11 má formu informačního standardu skládajícího se z terminologické a definiční vrstvy a principů tvorby informační struktury - kódování klinické informace. Položky klasifikace jsou v MKN-11 daleko více doplněny klinickými textovými definicemi. Nyní zahrnuje více než 55 tisíc kódovaných položek ke kódování mortality a morbidity (Mortality and Morbidity Statistics). Ty jsou vybrány z rozsáhlé terminologické vrstvy tzv. Foundation, která obsahuje více než 120 tisíc klinických termínů [1,2,3,].

\section{Nástroje WHO a struktura překládaných položek v MKN-11}

WHO připravila v souvislosti se zavedením MKN-11 radu nástrojů a doprovodných materiálů k jejímu užívání, jako je např. „ICD11 Browser ${ }^{\prime \prime}$, ICD-11 Coding Tool “ či nástroj pro trénování kódování „ICD-11 FIT“. V rámci dostupných nástrojů byla vytvořena také „Maintenance platform“. Ta umožňuje zobrazení základní terminologické vrstvy (Foundation), príspěvky a diskuse nad změnou obsahu a také různé jazykové verze. Překlad termínů bude probíhat v datovém modelu MKN-11. Datový model (Content model) obsahuje prvky uvedené níže (Obr. 1) pro každou položku vrstvy Foundation [4]. Ne každou součást datového modelu MKN-11 je však nutné překládat, některé pouze odkazují na jinou část datové struktury MKN-11.

\section{Překladové nástroje}

Jako překladový nástroj od WHO je k dispozici tzv. Multilingual Translation Tool (Součástí webové aplikace ICD-11 Maintenance platform; Obr. 2), který by mohl být ideálním prostredím pro překlad termínů do českého jazyka. Umožňuje např́klad navržení překladu (pokud byl daný text překládán $v$ jiné části MKN-11) nebo systém víceúrovňového schvalování překladu. Také přehledně zobrazuje, které části (a z kolika procent) jsou již přeloženy. Nevýhodou však zůstává časově i technicky náročné zrízení a management prístupů pro všechny zapojené odborné i jazykové experty. Další nevýhodou je anglické prostředí aplikace a nutnost proškolení všech uživatelů $\mathrm{k}$ práci $\mathrm{s}$ tímto prostředím.

1. ICD Concept Title

2. Hierarchy, Type and Use

2.1. Parents

2.2. Type

2.3. Use

3. Textual Definition(s)

4. Inclusion, Exclusion, and Index

4.1. Base Index

4.1.1. Synonyms

4.1.2. Narrower Terms

4.2. Base Exclusion

4.3. Inclusions

5. Clinical Description

5.1. Body System(s)

5.2. Body Part(s) [Anatomical Site(s)]

5.3. Morphologically Abnormal Structure

6. Manifestation Properties

6.1. Signs \& Symptoms

6.2. Findings

7. Causal Properties

7.1. Agents

7.2. Mechanisms

7.3. Risk Factors

7.4. Genomic Characteristics

8. Temporal Properties

9. Severity Properties

10. Functional Properties

11. Specific Condition Properties

12. Treatment Properties

13. Diagnostic Criteria

14. External Causes

Obrázek 1 - Datový model (Content model) MKN-11 s jednotlivými položkami vrstvy Foundation ${ }^{[4]}$ 


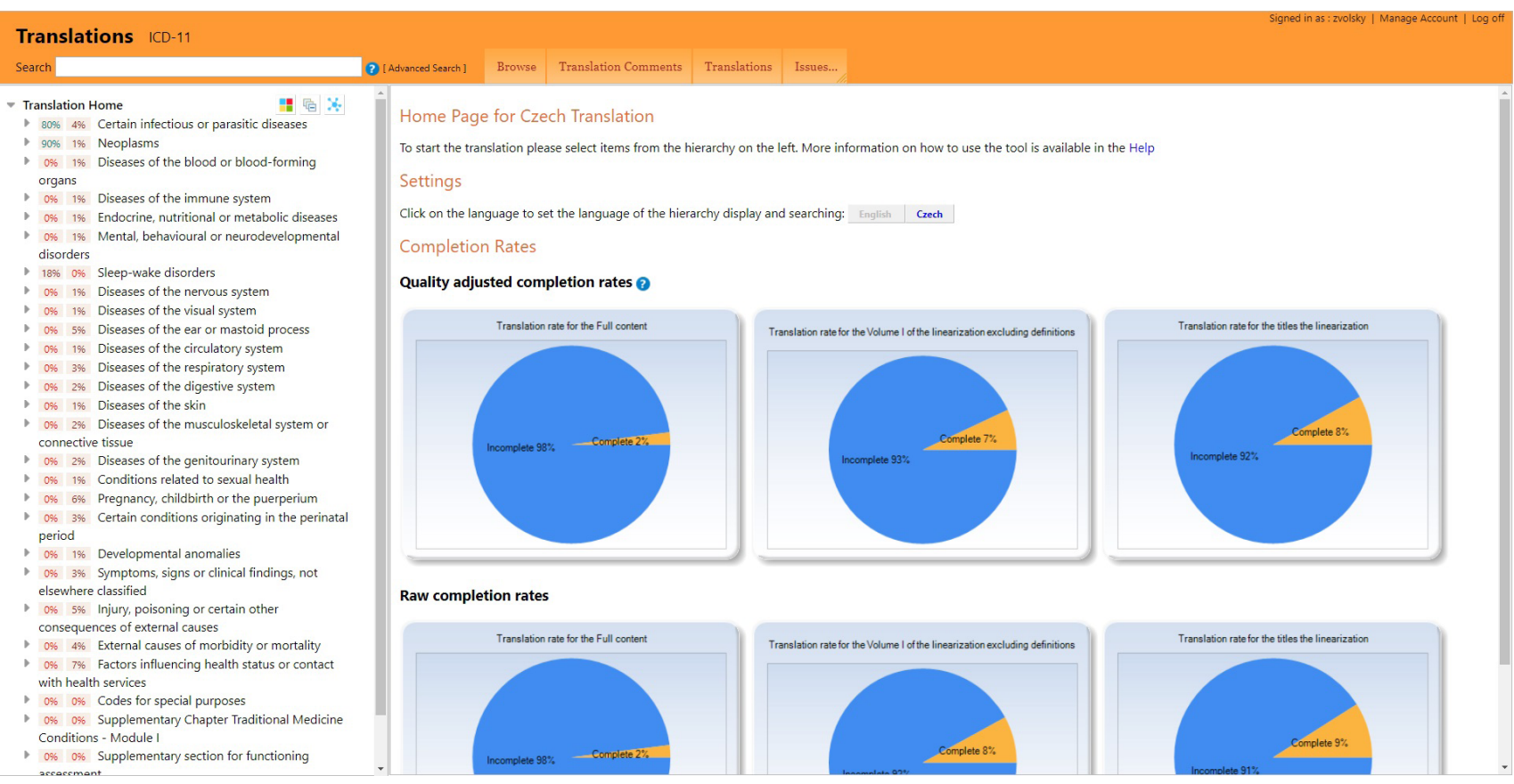

\section{Obrázek 2 - Screenshot webové aplikace Maintenance platform ukazující obsah nástroje Multilingual Translation Tool}

Alternativním řešením by mohlo být exportování anglické verze termínů do tabulkového souboru (napríklad ve formátu MS Office) a poté rozeslání jednotlivých částí expertům k překladu. Tyto samostatné části by bylo možné následně (za dodržení původního formátování) poskládat zpět do celku a prostřednictvím WHO nahrát do Maintenance Platform.

V př́padě zvolené varianty použití Multilingual Translation Tool bude prezentována práce $s$ tímto nástrojem prostřednictvím workshopů. $V$ prípadě varianty excelového souboru bude vytvořen přehledný manuál se všemi postupy, který bude následně k dispozici pro všechny zapojené experty.

\section{Navržený postup překladu}

Termíny určené k překladu budou rozděleny do tematických skupin podle odbornosti a následně rozeslány skupině expertů nominovaných Českou lékařskou společností. Rozdělení a distribuce souborů bude v kompetenci pracovníků ÚZIS ČR. Zároveň bude všem expertům distribuován metodický materiál sjednocující postup překladu. $V$ závislosti na volbě technické distribuce jednotlivých sad termínů bude provedeno hromadné nebo individuální zaškolení k práci se sadami termínů. Pokud některé oblasti budou zahrnovat více odborností, bude osloveno více expertů pro překlad téhož celku a výsledné dokumenty pak budou sjednoceny. Tento postup však bude využit jen v omezeném množství prípadů, aby se snížila pravděpodobnost překryvů, kdy by bylo nutné řešit konflikty v navržených překladech.

Následně budou překlady zkontrolovány editorem z ÚZIS ČR zejména z hlediska konzistence termínů, kompletnosti a uplatnění pravidel metodického materiálu pro překlad. Poté bude provedeno sjednocení sad termínů ( $v$ případě distribuce formou tabulek) a zjištění konfliktních překladů. Jazyková kontrola přeložených termínů bude provedena ve spolupráci s Ústavem dějin lékařství a cizích jazyků 1 . LF UK, případně dalšími oslovenými experty. Dalším krokem bude finalizace překladů, jejich uspořádání do celku, kontrola integrity, kontrola shody preferovaných termínů, identifikace přetrvávajících konfliktních překladů a jejich řešení.

$\checkmark$ poslední fázi bude překladová verze otevřena $k$ veřejnému připomínkování, a to na předpokládanou dobu 6 měsíců. Veřej- né připomínkování bude vyhlášeno zveřejněním tiskové zprávy na webových stránkách ÚZIS ČR, oslovením ČLS JEP a pacientských organizací prostřednictvím Ministerstva zdravotnictví ČR. Na řízení překladu se bude aktivně podílet Česká lékařská společnost Jana Evangelisty Purkyně, která bude nominovat jednotlivé experty. Mezi další organizace řídící překlad termínů bude patřit Ústav zdravotnických informací a statistiky ČR, Ministerstvo zdravotnictví ČR a Český statistický úřad. Před zadáním překladu odborníkům bude provedeno pečlivé zaškolení a představení překladových nástrojů.

\section{Předběžný harmonogram překladu}

ÚZIS ČR ve spolupráci s Univerzitou Karlovou zahajuje projekt Národní centrum pro medicínské nomenklatury a klasifikace. Projekt bude zahájen v letošním roce a bude probíhat po dobu 36 měsíců. Výstupem jedné z klíčových aktivit projektu bude právě český překlad MKN-11. Příprava překladu, samotný překlad a následná implementace budou probíhat podle následujícího harmonogramu (Tab. 1).

Tabulka 1 - Předběžný časový harmonogram překladu MKN-11 do českého jazyka

\begin{tabular}{|c|c|c|}
\hline \multirow[t]{3}{*}{$\begin{array}{l}\text { Rok } \\
2020\end{array}$} & Měsíce 1-3 & $\begin{array}{l}\text { bude sestavena odborná rada překladu } \\
\text { MKN-11 }\end{array}$ \\
\hline & Měsíce 4-6 & $\begin{array}{l}\text { bude probíhat nominace a nasmlouvání } \\
\text { expertů na překlad a rozdělení práce }\end{array}$ \\
\hline & Měsíce 7-12 & $\begin{array}{l}\text { proběhne } 1 \text {. fáze překladu a bude } \\
\text { vyhotovena } 1 \text {. verze překladového souboru }\end{array}$ \\
\hline \multirow[t]{3}{*}{$\begin{array}{l}\text { Rok } \\
2021\end{array}$} & Měsíce 13-18 & $\begin{array}{l}\text { proběhne ověření } 1 \text {. verze překladu, } \\
\text { doplnění chybějících částí a řešení } \\
\text { problémů editory }\end{array}$ \\
\hline & Měsíce 19-21 & bude zahájena jazyková korektura překladů \\
\hline & Měsíce 22-24 & $\begin{array}{l}\text { 2. verze překladu bude připravena } \\
\text { k oponentuře, proběhne alespoň měsíční } \\
\text { oponentura }\end{array}$ \\
\hline
\end{tabular}




\begin{tabular}{|l|l|l|}
\hline $\begin{array}{c}\text { Rok } \\
2022\end{array}$ & Měsíce 25-27 & $\begin{array}{l}\text { překlad bude revidován na základě vstupů } \\
\text { z oponentury a publikován jako další } \\
\text { jazyková verze na mezinárodním portále } \\
\text { WHO pro MKN-11 }\end{array}$ \\
\hline Měsíce 28-36 & $\begin{array}{l}\text { bude nastaven revizní proces překladů } \\
\text { a připomínek a zároveň bude probíhat } \\
\text { překlad oprav a pravidelných revizí WHO, } \\
\text { v tomto období bude také probíhat } \\
\text { tvorba doplňujících produktư k vlastnímu } \\
\text { překladu (prohližeč s doplňkovými } \\
\text { funkcemi, výukové materiály) }\end{array}$ \\
\hline
\end{tabular}

\section{Současný stav překladu}

V prvním kroku již byl do Translation Tool nahrán kompletní soubor termínů MKN-10, který nyní zaujímá asi $2 \%$ obsahu MKN-11 (Obr. 2). Z hlediska přeložených termínů linearizace "Mortality And Morbidity Statistics" se jedná o asi $7 \%$ a o $8 \%$ názvů kódovaných položek. I překlady importované z MKN-10 by měly být podrobeny posouzení správnosti klinickým expertem. Byla zajištěna prístupová práva do Translation Platform pro referenční a obecné překladatele. Dále byly přeloženy technické termíny a webové rozhraní, které je nyní již k dispozici v českém jazyce a čítá okolo 322 přeložených položek.

\section{Závèr}

Zavedení MKN-11 umožní větší podrobnost statistických výstupů a analýz zdravotnických dat nad rámec současných možností. Dojde především k rozšíření struktury a informačních možností MKN-11 a k lepšímu a podrobnějšímu popisu zdravotního stavu. MKN-11 bude také vhodnější k použití v aplikacích elektronického zdravotnictví a při konstrukci strukturovaného elektronického zdravotního záznamu.

ÚZIS ČR zahajuje tvorbu české verze MKN-11 založené na překladu a adaptaci mezinárodního vzoru. Překlad a adaptace budou prováděny $v$ těsné spolupráci se zástupci klinických oborů nominovaných odbornými společnostmi tak, aby byla zajištěna přesnost klinické terminologie a kompletnost klinického obsahu.

$\mathrm{K}$ tvorbě české verze jsou připravené mezinárodní webové nástroje, případně oběh obsahu v podobě tabulek. Tvorba české verze MKN-11 by měla být dokončena $v$ roce 2022 , zároveň bude spuštěn pravidelný aktualizační proces. Na vlastní překlad bude navazovat testování obsahu a další kroky směřující k implementaci MKN-11 v České republice.

\section{Literatura}

[1.] ICD-11 Implementation or Transition Guide, Geneva: World Health Organization; 2019; License: CCBY-NC-SA3.0IGO.

[2.] ICD-11 Reference Guide, Geneva: World Health Organization; 2019.

[3.] Eleventh revision of the International Classification of Diseases, Report by the Director-General; Document No. EB144/22; Executive Board; 144th session; 12 December 2018.

[4.] Tu S. W. et al. (2010): A Content Model for the ICD-11 Revision.

\section{Kontakt}

Mgr. Kateřina Hanušová

Ústav zdravotnických informací

a statistiky ČR

e-mail: katerina.hanusova@uzis.cz

RNDr. Šárka Daňková

Ústav zdravotnických informací

a statistiky ČR

e-mail: sarka.dankova@uzis.cz

MUDr. Miroslav Zvolský

Ústav zdravotnických informací

a statistiky ČR

e-mail:miroslav.zvolsky@uzis.cz 